\title{
Introducing an innovation promotion model for construction projects
}

\author{
Abstract \\ Purpose - This research is on investigating and modeling the complex dynamics of \\ innovation enablers in construction projects aiming to develop a framework identifying \\ actions for clients to promote innovation.
}

Design/methodology/approach - Through a comprehensive literature review, a conceptual model was previously derived to explain the client-driven enablers in promoting innovation. This was tested using the data from 131 Australian construction projects. Statistical analysis was conducted on the data using factor analysis and correlation analysis to test the model, which was validated using the case study approach. The testing and validating aspects are explained in this paper.

Findings - The constructs of the recommended model are idea harnessing; relationship enhancement; incentivization; and project team fitness.

Research limitations/implications - The difficulty of analyzing the complex dynamics happening within projects in relation to innovation has been a barrier to progress research in this area. The introduction of this model would pave the way for researchers to explore this area with ease.

Originality/value - As revealed in the detailed literature review undertaken, this is the first time that a comprehensive study has been conducted to identify client-led innovation enablers for construction projects. The results would benefit industry practitioners to achieve enhanced project outcomes in construction projects through innovation.

Key words construction industry, client, creativity, enablers, incentives, innovation, project level, incentivization, relationship, project manager, project team, organization.

Paper type Research paper

\section{Introduction}

There is a significant amount of anecdotal information that suggests innovation is the underpinning driver that leads to enhanced outcomes in different kinds of projects (Duffield \& Maghsoudi 2013). Innovation can bring in a number of benefits to construction projects. Summarizing the findings of many researchers, Fernando et al. (2019) produced a list of benefits to construction projects from innovation such as decreased cost, higher quality, health and safety improvements, minimized waste, reduced carbon emissions, additional cost savings in future projects due to gained experience, future collaboration along the supply chain, knowledge transfer to inform future projects, client and end user satisfaction, improved quality of life for local people, increased productivity, competitive advantage, organizational effectiveness, increased organizational commitment, higher organizational motivation, and enhanced corporate image and recognition.

Innovation is turning imagination into practical reality. As there is no limit to human imagination, the benefits from innovation to the construction industry have no limit. Therefore, it is vital to look into how innovation could be used to benefit construction 
projects. Unfortunately, the research in this area has not progressed sufficiently to provide necessary guidance to benefit from innovation.

Many researchers have identified this knowledge gap. For example, Brockmann et al. (2016) stated that we are lacking knowledge on the details of innovation in construction projects. Ozorhon (2012) commented that much of construction innovation is codeveloped at the project level and most of the literature has focused on investigating innovation at the firm level, and the project level has largely been ignored. This argument was supported by Chen (2014) who added that despite the panoply of studies that use a wide variety of measures to describe innovation outcomes and the input characteristics that affect those outcomes as well as firm performance, most studies focus on firms engaged in innovation and relatively few studies explore projects engaged in innovation.

The situation with regard to innovation research at construction project level can be summed up by the findings of Keegan and Turner (2002), who reported that a review of articles published in the main project management journals (a total of 663 papers) had no mention of innovation as an important topic. Many other researchers supported this claim. For example, Uchitpe et al. reported in 2016 of a study conducted to predict the potential research areas that could appear in the foreseeable future of project management research using a quantitative approach. This study utilized different keywords that had been extracted from all publications of a reputed project management journal over a period of five years (i.e. 2009-2013). Innovation was not among the research areas that was found in this study. However, a burst analysis from 2006 to 2012 conducted by Pollack and Adler (2015) to understand more recent developments in project management found that 'Innovation' and 'New Product Development' were among most frequently used keywords when searching for 'Project Management'. They searched keywords of research publications in the ISI and Scopus databases, in response to the search term 'Project Management'. With this finding, they suggested that project management is more recently being viewed as a potential way of driving or managing change and innovation within organizations. However, there was no mention about project level innovation in this research paper either, suggesting that project level innovation in project management area is still not identified as a key focus area.

For the study presented in this paper, over 300 papers (from 1965 to 2019), majority from peer-reviewed journals, were reviewed. The review failed to identify a proper definition for project level innovation, let alone considerable research on the subject area. From the literature review, only 5 papers could be identified as discussing project level innovation directly, indicating that project-level innovation is under-researched. Even these papers concentrated mainly on general factors such as project size and complexity, market conditions, government policies and regulations, most of which are difficult for the clients to manipulate at the project level. There was not a single paper found comprehensively researched client-led enablers that could be implemented to facilitate innovation in construction projects.

This research study was inspired by the importance of innovation within the construction context, the capability of clients to enhance innovative outcomes in construction projects and the motivation to bridge the knowledge gap to progress innovation research at the project level. It envisaged in studying the actions that clients can take to enhance innovative outcomes and simplifying them in order to clearly explain the client-driven innovation process in a construction project. The following were the objectives of the study:

1. To develop a model using identified categories as constructs that encapsulates their relationship with innovative outcomes and their uncovered relationships with each 
other, which can be used to describe the complex dynamics related to innovation in construction projects;

2. To empirically-test the model using the data from construction projects; and

3. To validate the developed model through case studies of selected construction projects.

To achieve these objectives, the authors used the previously identified conceptual model and the framework which described innovation enablers applicable to construction projects. They were described in the paper published by Fernando et al. (2019). More information including the comprehensive literature review undertaken to derive the model can also be found in Fernando (2019).

The present research was undertaken following the steps outlined below.

1. Developing and conducting a questionnaire survey (primary data collection);

2. Undertaking a statistical analysis on the data to test the model; and

3. Validating the model using the case study approach.

The above steps are discussed in detail in the following sections.

\section{Conceptual framework and the model}

This section will discuss how the conceptual framework was developed leading to the derivation of a model. Before proceeding much into this project level research, it is necessary to provide a definition to construction innovation at the project level in order to have clarity and a common understanding of this subject area.

\section{Defining project level innovation}

The comprehensive literature review undertaken for the study failed to identify a suitable definition. Therefore, it was considered necessary to develop a new definition for project level innovation. An intensive process was applied for this purpose including the preparation of a list of construction innovation related definitions, identification of attributes considered necessary to describe innovation, proposing a definition and testing with ten industry experts. The following was the accepted definition after undergoing the procedure mentioned above:

"With respect to projects, innovation can be regarded as the application of ideas for new or improved products (including materials, plant and equipment), software, technologies, methods, practices and systems designed to benefit the project".

As this definition is on projects in general and has nothing to do with construction projects, it was tested with eleven project managers from industries such as mining, mineral processing, oil and gas, information technology, steel manufacturing, and power. All agreed that the definition was applicable to their projects, confirming that the definition can be used to describe project level innovation in general.

Having arrived at a definition to describe project level innovation, the conceptual framework, which was identified using the literature review is explained next.

\section{Conceptual framework}

After undertaking a comprehensive literature review and obtaining industry expert input, Fernando et al. (2019) identified a simple framework to describe client-led innovation enablers at the project level in the context of construction projects. 
The framework developed consisted of the following categories of client-led innovation enablers: (1) idea harnessing (strategies that can be used for the generation of new and beneficial ideas and implementing them) ; (2) relationship enhancement (actions that can be used to improve relationship between parties engaged in the project); (3) incentivization (the types of incentives/ rewards that can be provided to promote innovative activities); and (4) project team fitness (deliberate actions that can be taken to strengthen the project team and improve its capability to focus on innovative activities). They are briefly explained below.

\section{Idea harnessing}

Idea harnessing is the group of actions that client can take to generate and implement new and beneficial ideas. It includes the use of idea generation tools (such as brainstorming, scenario planning, risk assessment planning, life cycle costing, value engineering and value management) and techniques (such as engaging suppliers earlier on, following new research in the field of work, using inputs from experienced personnel, key stakeholders, contractors, suppliers and fellow staff and workers, using best practices and using captured project learnings from completed projects).

\section{Relationship enhancement}

No innovation could be achieved in an adversarial environment. Relationship enhancement is employing actions to improve relationship within the project team and between parties to the project such as contractors, consultants and suppliers. This includes implementing strategies such as partnering and alliancing.

\section{Incentivization}

Research shows that innovative activities in a project could be enhanced by encouraging and providing incentives or rewards. They could also be monetary (such as payments to contractors and to other key suppliers if they undertake innovative activities) or nonmonetary (such as giving future contracts to innovative contractors). Incentives could be given to individuals and to teams and they could be from the client's team as well as from parties contributing to the project.

\section{Project team fitness}

All the actions mentioned above may not work unless the client's team is capable and focused on enhancing innovation. The actions clients can take to increase the capability of the team are categorized under project team fitness. They include:

1. Creating a capable project team by appointing suitable team members and develop the team to undertake activities to enhance innovation performance.

2. Establishing a strong supportive environment for the project team to undertake innovative activities.

Such strategies help the client's project team to understand the concept of innovation better and how to facilitate the same, to encourage and motivate the team to facilitate innovation and to obtain the support and facilities from the client organization to deal with innovative activities.

\section{The conceptual model}

The identification of client-led innovation enabler categories mentioned in the previous section paved the way to derive a conceptual model to describe the innovation process in a 
construction project. The categories are represented as constructs in the model, shown in Figure 1.

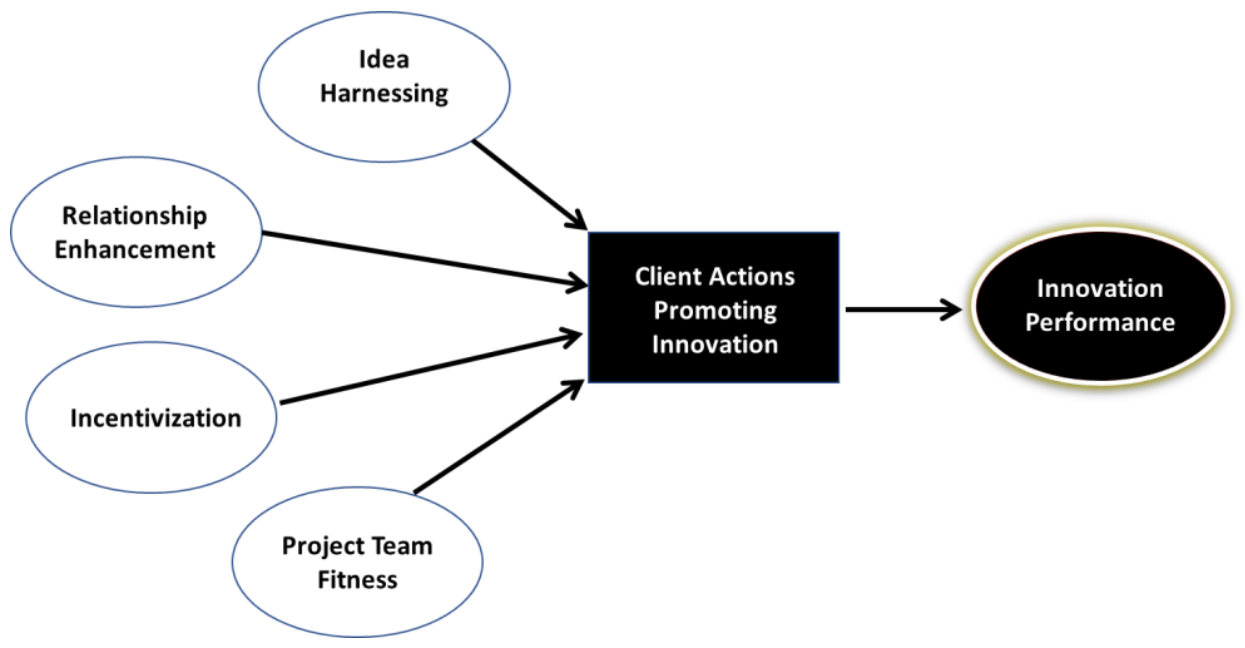

Figure 1. Conceptual model.

The model portrays idea harnessing, relationship enhancement, incentivization and project team fitness as independent constructs, having an influence on innovation performance as the dependent construct. Increased efforts into these independent constructs increase innovation performance. Independent constructs are also interrelated with one another promoting each other. This paper describes the research undertaken to test this model and validate the same.

\section{Model testing}

\section{Questionnaire survey}

The questionnaire requested participants to provide details of one of their recent construction projects, which they considered innovative. It had the following parts: (1) details of the selected project; (2) performance of client-led enablers with respective to the innovative performance of the project; and (3) background information about the participants and their organizations.

Project information (Part 1) requested information of the project such as the main engineering area, delivery type, cost and the complexity. The questions related to client-led enabler categories requested in Part 2 were under the following categories: idea harnessing (Group A), relationship enhancing (Group B), incentivization (Group C) and project team fitness (Group D). This section also included the participant's perception of the project's innovative performance (Group E).

The last section (Part 3) consisted of questions related to the background of participants and their organisations such as gender, level of education, age group, professional experience, main engineering area of the organisation, occupation and type of the organisation.

The questionnaire was developed using the following:

- Findings from a comprehensive review of literature;

- Questionnaire items used in previous similar research; and

- The suggestions provided by industry experts through interviews. 
The questionnaire was distributed to over 300 construction industry practitioners by post and through emails. They were identified through an online search engine and included all engineering statutory bodies at federal, state and local government levels (example: road authorities, city councils), construction companies, other engineering service suppliers such as consultants, designers, and geotechnical service providers. In total, 131 valid responses were received, representing about $44 \%$ effective response rate.

The data collected were statistically analysed using factor analysis and correlation analysis, the details of which are given in subsequent sections.

\section{Factor analysis}

According to Bhattacherjee (2012), among competing explanations that sufficiently explain the observed evidence, the simplest theory (i.e., one that uses the smallest number of variables or makes the fewest assumptions) is the best and therefore, a theory should be simplified and generalizable explanations of reality. The questionnaire used in this research had 62 variables under the groups of idea harnessing, relationship enhancement, incentivization and project team fitness. It was necessary to reduce the variables to arrive at a simple theory. This was done by subjecting the variables through a factor analysis. As stated by Yong and Pearce (2013), the broad purpose of factor analysis is to summarize data so that relationships and patterns can be easily interpreted and understood. It is normally used to regroup variables into a limited set of clusters based on shared variance.

The data set to be statistically analysed using factor analysis consisted of 5-point Likert scale ("strongly agree", "agree", "neutral", "disagree", "strongly disagree") variables. Before conducting the factor analysis, data were subjected to missing data analysis and the analysis of outliers, which reduced the initial 131 set of data to 115 . Initial screening using histograms and Shapiro Wilk tests confirmed that variables generally did not follow a normal distribution.

An analysis of scale reliability was performed to ensure that the set of measurement scales consistently and accurately captured the meaning of the model constructs, which consisted of examining internal consistency and item-total correlations. The internal consistency, measured using Cronbach's Alpha, was 0.952, much above the recommended minimum value of 0.70 (Gennarelli and Goodman, 2013). An item-total correlation test was performed to check if any item in the set of data was inconsistent with the average behaviour of the others, and thus can be discarded. There was one item with a value less than 0.30 as recommended by Field (2013), which was dropped from further analysis.

The other guidelines, which were followed during the analysis, are briefly mentioned below.

- The Kaiser-Meyer-Olkin (KMO) Measure of Sampling Adequacy was to be above 0.50 and the Bartlett's Test of Sphericity was to be significant $(p<.05)$ (Williams et al., 2010).

- The lower level for the test for communality was taken as 0.2 (Yong and Pearce, 2013).

- Used the Principal Axis Factor for extracting factors (Yong and Pearce, 2013).

- Both Eigenvalues and Scree Plots were used to determine the number of factors to be extracted with Eigenvalues greater than 1 (Field, 2013).

- The factorability in the correlation matrix was limited to 0.3 (Williams et al., 2010).

- Oblique rotational method was used for rotation (Williams et al., 2010) with the rotation technique of Promax (Yong and Pearce, 2013).

- Factor loadings were kept above 0.3 (Hair et al., 2006). 
- Minimum number of items per factor was taken as three (Costello and Osborne, 2009).

Taking into consideration of the above, the factor analysis was undertaken using the SPSS Version 23. The analysis was performed separately for independent variables (i.e., those came under idea harnessing, relationship enhancing, incentivization and project team fitness) and dependent variables coming under innovative performance. Several iterations were performed to achieve a set of factors, which could be described in practical terms.

\section{Factor analysis results Independent variables}

Independent variables coming under idea harnessing, relationship enhancing, incentivization and project team fitness, initially had 44 variables. These were reduced to 41 after removing crossloaded variables and variables with factor loadings less than 0.3 , under 8 separate factors named as project team attributes, support to the project team, nature of relationship, project team member attributes, internal recognition, client organization, designers and contractors and incentivization. The factors derived for independent variables are given in Table I together with their assigned names and factor loadings.

\begin{tabular}{|c|c|c|}
\hline Factor Name & Variables under factors & $\begin{array}{l}\text { Factor } \\
\text { loading }\end{array}$ \\
\hline \multirow{12}{*}{$\begin{array}{l}\text { Project team } \\
\text { attributes }\end{array}$} & 2D4.2 Felt free to talk & 0.765 \\
\hline & 2D4.1 All were treated equally & 0.725 \\
\hline & 2D4.4 No difficulty in forming teams & 0.716 \\
\hline & 2D4.3 Ideas became team ideas & 0.715 \\
\hline & 2D1.4 PM made quick decisions & 0.683 \\
\hline & 2D1.5 PM protected the team & 0.614 \\
\hline & 2D3.2 Project team members motivated & 0.500 \\
\hline & 2D4.5 No blame game & 0.442 \\
\hline & $\begin{array}{l}\text { 2D1.1 PM sought out, encouraged and promoted new ideas/ technology/ } \\
\text { processes }\end{array}$ & 0.423 \\
\hline & 2A2.1 We used inputs from experienced personnel & 0.349 \\
\hline & 2A2.4 We captured project learnings & 0.319 \\
\hline & 2A2.3 We followed new research & 0.297 \\
\hline \multirow{5}{*}{$\begin{array}{l}\text { Support to the } \\
\text { project team }\end{array}$} & 2D2.1 Project team was provided with training to improve team skills & 0.923 \\
\hline & 2D2.2 Project team was provided with training to improve knowledge & 0.876 \\
\hline & $\begin{array}{l}\text { 2D2.4 Project team had opportunities to be exposed to best national and } \\
\text { international practices }\end{array}$ & 0.756 \\
\hline & 2D2.3 Project team had opportunities to be exposed to others & 0.636 \\
\hline & 2D2.5 Project team was provided with training to implementers & 0.526 \\
\hline \multirow{4}{*}{$\begin{array}{l}\text { Nature of } \\
\text { relationship }\end{array}$} & 2B2.2 Had conducive culture within teams & 0.937 \\
\hline & 2B2.4 Had excellent relationships with other teams & 0.861 \\
\hline & 2B2.1 Respected each other teams & 0.715 \\
\hline & 2B2.3 Had good relationships with key stakeholders & 0.669 \\
\hline \multirow{2}{*}{$\begin{array}{l}\text { Project team } \\
\text { member attributes }\end{array}$} & 2D3.4 Project team members had considerable knowledge and experience & 0.881 \\
\hline & 2D3.6 Project team members had strong relationships with customers & 0.650 \\
\hline
\end{tabular}




\begin{tabular}{|c|c|c|}
\hline & 2D3.3 Project team members diverse persons & 0.636 \\
\hline & 2D3.1 Project team members helpful & 0.496 \\
\hline & 2D3.5 Project team members had exposure to innovation & 0.471 \\
\hline & 2D3.7 Project team members considered innovation as a day-to-day duty & 0.314 \\
\hline \multirow{4}{*}{ Internal recognition } & $2 \mathrm{C} 1.2 \mathrm{We}$ recognized idea implementers & 0.799 \\
\hline & $2 \mathrm{C} 1.1$ We recognized idea generators & 0.710 \\
\hline & 2A2.6 We had implementers to help idea generators & 0.422 \\
\hline & 2D1.3 PM earned respect & 0.413 \\
\hline \multirow{3}{*}{ Client organization } & 2D5.2 Client organization relaxed technical regulations/ specifications & 0.619 \\
\hline & 2D5.1 Client organization supported innovative activities & 0.612 \\
\hline & 2D5.3 Client organization had characteristics of an innovative organization & 0.506 \\
\hline \multirow{3}{*}{$\begin{array}{c}\text { Designers and } \\
\text { contractors selection }\end{array}$} & 2C1.6 Selecting designers and contractors - used innovation history & 0.859 \\
\hline & 2C1.5 Selecting designers and contractors - used innovative proposals & 0.835 \\
\hline & 2C1.7 Selecting designers and contractors - used innovation performance & 0.307 \\
\hline \multirow{4}{*}{ Incentivization } & 2C1.4 Rewarded with personal incentives & 0.649 \\
\hline & 2C1.3 Rewarded with financial incentives & 0.548 \\
\hline & 2C1.9 Selected contract types such as alliances & 0.500 \\
\hline & 2C1.8 Included contract clauses to share savings & 0.467 \\
\hline
\end{tabular}

\section{Table I. Factor analysis results for independent variables}

\section{Dependent variables}

Dependent variables coming under innovative performance, initially had 18 variables. These were reduced to 14, after removing crossloaded variables and variables with less than 0.3 factor loadings, under 3 separate factors named as project outcomes, project recognition and project usage. The factors derived for dependent variables are given in Table II together with assigned names and factor loadings.

\begin{tabular}{|l|l|c|}
\hline \multirow{4}{*}{ Factor Name } & \multicolumn{1}{|c|}{ Variables under factors } & \multicolumn{1}{c|}{$\begin{array}{c}\text { Factor } \\
\text { loading }\end{array}$} \\
\hline \multirow{5}{*}{ Project outcomes } & 2E2.3 Project outcome: Sustainable outcomes and reduced waste & 0.858 \\
\cline { 2 - 3 } & 2E2.1 Project outcome: Operational goals & 0.819 \\
\cline { 2 - 3 } & 2E2.4 Project outcome: Satisfied project team & 0.788 \\
\cline { 2 - 3 } & 2E2.2 Project outcome: Satisfied customers & 0.732 \\
\cline { 2 - 3 } & $\begin{array}{l}\text { 2E2.5 Project outcome: Increased productivity and competitive } \\
\text { advantage }\end{array}$ & 0.582 \\
\cline { 2 - 3 } & $\begin{array}{l}\text { 2E2.6 Project outcome: Positive organizational and professional } \\
\text { learning }\end{array}$ & 0.471 \\
\hline \multirow{5}{*}{ Project recognition } & 2E3.3 Highly commended in the media & 0.812 \\
\cline { 2 - 3 } & 2E3.1 Project personnel received internal recognition & 0.807 \\
\cline { 2 - 3 } & 2E3.4 External recognition in professional bodies & 0.790 \\
\cline { 2 - 3 } & 2E3.2 Project received internal recognition & 0.788 \\
\hline
\end{tabular}




\begin{tabular}{|l|l|c|}
\cline { 2 - 3 } & $\begin{array}{l}\text { 2E1.4 We used improved advanced business or procurement } \\
\text { techniques, processes and systems }\end{array}$ & 0.794 \\
\cline { 2 - 3 } Project usage & $2 \mathrm{E} 1.2$ We used improved materials, products, plant, and equipment & 0.738 \\
\cline { 2 - 3 } & $\begin{array}{l}\text { 2E1.3 We used improved computer software/ hardware, models and } \\
\text { communication systems }\end{array}$ & 0.650 \\
\hline & $2 \mathrm{E} 1.1$ We used improved technologies, methods and practices & 0.562 \\
\hline
\end{tabular}

\section{Table II. Factor analysis results for dependent variables}

Having derived the factors that formed the constructs of the model, it was necessary to find their relationships. Correlation analysis was used to assess the relationship of each construct with innovation performance and the relationship with each other/ which is discussed in the next section.

\section{Correlation Analysis}

Associations between variables were analysed using correlation, which is based on covariance. As Field (2013) explained, covariance is a good measurement to assess whether two variables are related to each other. A positive covariance indicates that as one variable deviates from the mean, the other variable deviates in the same direction. On the other hand, a negative covariance indicates that as one variable deviates from the mean, the other variable deviates in the opposite direction. Correlation analysis uses the correlation coefficient to assess the relationship between variables.

Correlation is measured by the correlation coefficient, which represents the strength of the putative linear association between the variables in question. It is a dimensionless quantity that takes a value in the range -1 to +1 . A correlation coefficient of zero indicates that no linear relationship exists between two continuous variables, and a correlation coefficient of -1 or +1 indicates a perfect linear relationship (Mukaka, 2012).

There are different correlation coefficients to handle the special characteristics of variables. Most popular correlation coefficients are the Pearson's correlation coefficient, the Spearman's rank correlation coefficient and the Kendall's tau correlation coefficient (Chok, 2010). Pearson's is calculated if the two variables are continuous and at least one is distributed normally. Spearman's rank correlation coefficient would be calculated if neither variable was distributed normally or if one of the variables was discrete (Sedgwick, 2012). The Kendall's tau can be used to assess and test correlations between non-interval scaled ordinal variables. It is considered to be equivalent to the Spearman rank correlation coefficient (Bolboaca and Jäntschi, 2006). Both Spearman's rank correlation coefficient and the Kendall's tau correlation coefficient were used in this analysis as the data were not normally distributed.

When discussing correlation, it is important to discuss partial correlation as well. If the need is in finding whether or to what extent there is a numerical relationship between two variables of interest, using their correlation coefficient will give misleading results if there is another, confounding, variable that is numerically related to both variables of interest. This misleading information can be avoided by computing the partial correlation coefficient. Partial correlation is the correlation of one variable with another, controlling for a third or additional variables (Asuero et al., 2006). In probability theory and statistics, partial 
correlation measures the degree of association between two random variables, with the effect of a set of controlling random variables removed.

When interpreting the values of Spearman's correlation coefficient and Kendall's tau obtained in the analysis, the approach taken by Kumar et al. (2018) was adopted. In their research in the medical area using the Spearman's correlation coefficient ( $r$ ), they adopted the convention as given in Table III.

\begin{tabular}{l|l} 
Degree of association & Value of ' $r$ ' \\
\hline Strong & $1-0.7$ \\
\hline Moderate & $0.7-0.5$ \\
\hline Low & $0.5-0.3$
\end{tabular}

\section{Table III. Spearman's Correlation Coefficient Classification}

One of the requirements for using the Spearman's and Kendall's Correlation tests is that the underlying relationship should be monotonic (Chok, N.S., 2010), which was checked through the observation of scatter plots. All the scatter plots showed a linear relationship between each pair of variables.

\section{Correlation analysis results}

Spearman's Correlation Coefficient test results are shown in Table IV.

\begin{tabular}{|c|c|c|c|c|c|c|c|c|c|}
\hline & $\begin{array}{c}\text { Project } \\
\text { team } \\
\text { attributes }\end{array}$ & $\begin{array}{c}\text { Support to } \\
\text { the project } \\
\text { team }\end{array}$ & $\begin{array}{l}\text { Nature of } \\
\text { relationship }\end{array}$ & $\begin{array}{l}\text { Project } \\
\text { team } \\
\text { member } \\
\text { attributes }\end{array}$ & $\begin{array}{l}\text { Internal } \\
\text { recognition }\end{array}$ & $\begin{array}{c}\text { Client } \\
\text { organisation }\end{array}$ & $\begin{array}{l}\text { Designers } \\
\& \\
\text { contractors } \\
\text { selection }\end{array}$ & Incentivisation & $\begin{array}{c}\text { Innovation } \\
\text { performance }\end{array}$ \\
\hline Project team attributes & 1.000 & 335 & 467 & 39 & 495 & 425 & 47 & 322 & 393 \\
\hline Support to the project team & 335 & 1.000 & 114 & 291 & 423 & 391 & 363 & 489 & 359 \\
\hline Nature of relationship & 467 & 24 & 1.000 & 348 & 386 & 33 & 320 & 198 & 324 \\
\hline Project team member attributes & 53 & 2 & 348 & 1.000 & 356 & 446 & 385 & 361 & 39 \\
\hline Internal recognition & 495 & 423 & 386 & 356 & 1.000 & 475 & 442 & 418 & 410 \\
\hline Client organisation & 425 & 391 & 333 & 446 & 475 & 1.000 & 478 & (5) & $39 / 1 / 1$ \\
\hline Designers \& contractors selection & 437 & 363 & 320 & 385 & 442 & 478 & 1.000 & 462 & 461 \\
\hline Incentivisation & 322 & 489 & 192 & 361 & 418 & 30 & 462 & 1.000 & 429 \\
\hline Innovation performance & 59 & 359 & 324 & 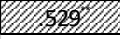 & 410 & 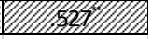 & 461 & 429 & 1.000 \\
\hline \multicolumn{10}{|l|}{ Correlation Coefficient $(r)$ strength } \\
\hline & \multicolumn{3}{|c|}{ moderate ( $r$ between 0.7 and 0.5 ) } & & & & & & \\
\hline & \multicolumn{3}{|c|}{ low ( $\mathrm{r}$ between 0.5 and 0.3 ) } & & & & & & \\
\hline & \multicolumn{2}{|c|}{ very low ( $r$ up to 0.3 ) } & & & & & & & \\
\hline & & & & & & & & & \\
\hline
\end{tabular}

\section{Table IV. Spearman's Correlation Coefficient test results}

Correlation analysis using the Spearman's Correlation test revealed the following:

1. The significance $(p)$ value of all the correlation coefficients were $<0.05$, rejecting the null hypothesis that there was no association between the variables in the underlying population. This means that all the variables were correlated to each other.

2. All the correlation coefficients were positive indicating a positive association between variables.

3. All Bootstrap 95\% upper and lower confidence levels were positive, indicating further the associations were in positive territory. 
4. Most coefficients can be considered as low (up to 0.5), but there were a few with moderate values (between 0.5 and 0.7 ).

Kendall's Correlation test results showed the following:

1. The significance $(p)$ value of all the correlation coefficients were $<0.05$, rejecting the null hypothesis that there was no association between the variables in the underlying population. This means that all the variables were correlated to each other.

2. All the correlation coefficients were positive indicating a positive association between variables.

3. All Bootstrap 95\% upper and lower confidence levels were positive, indicating further the associations are in positive territory.

One notable difference between Spearman's and Kendall's test results was that the correlation coefficients produced in Kendall's test were low in value, none exceeding 0.5.

Partial correlation was analysed using the Spearman's correlation coefficient. As the SPSS software has no readily available procedure to perform partial correlation for nonparametric data, the analysis was done by coding script into the SPSS Syntax Editor.

The results of the partial correlation analysis revealed the following:

- Only project team attributes, project team member attributes and client organization characteristics showed significant partial correlations with innovation performance.

- The project team attributes variable showed the strongest association (correlation coefficient of 0.593 ).

- The associations of project team member attributes and client organization characteristics were somewhat similar (correlation coefficients of 0.529 and 0.527 respectively).

- All significant associations were positive.

The findings of the factor analysis and the correlation analysis produced an empirical model as shown in Figure 2. The dotted arrows connecting each construct and innovation performance indicate that each construct is correlated to each other and they each are correlated with innovation performance. The black arrows starting from project team attributes, project team member attributes and client organization and ending up with innovation promotion indicate that these three constructs have correlation with innovation promotion irrespective of others (as revealed by partial correlation analysis). 


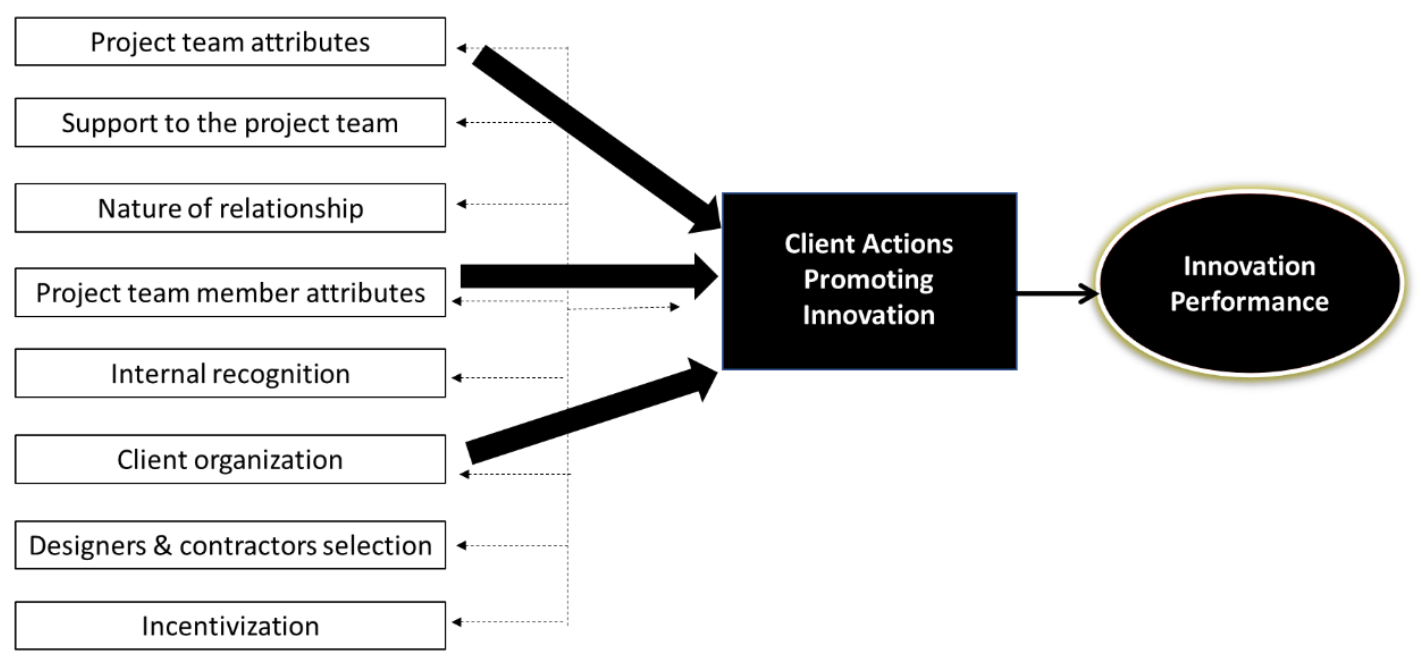

Figure 2. Empirical model

It can be seen that the statistical analysis produced the empirical model that is slightly different from the conceptual model. Instead of four constructs in the conceptual model the empirical model produced 8 constructs, seemingly different in interpretation.

\section{Model validation}

The approach selected to validate the conceptual model was the case study method. As explained by Rowley (2002), a case study is an empirical inquiry that investigates a contemporary phenomena within its real life context, especially when the boundaries between phenomenon and context are not clearly evident.

Case studies provided the best research validation method for this study due to the following reasons:

- The research was focussed on how clients could promote innovation in construction projects and why some client actions promote innovation. Case studies is the preferred way of exploring research questions involving 'how' and 'why' or 'who' (Crowe et al., 2011).

- In innovation research, it is difficult to have a practical control of factors and to assess their impact on innovation due to the complex and unique nature of construction projects and the innovation process. As stated by Schell (1992), case study approach is preferred when there is no practical form of control of the events or phenomenon and if there is a high likelihood of focus on contemporary events.

- As noted by Asuero et al. (2006), a measure of statistical relationship, such as a correlation coefficient, should never be used to deduce a causal connection and the ideas on causation must come from the practical world, outside statistics. Case studies give the opportunity to test the findings in a real world situation.

The information sources for case studies can be either single or multiple. Single sources of information provide a holistic overview of the phenomena, while multiple sources allow for the use of methodological triangulation (Schell, 1992). The more cases that can be marshalled to establish or refute a theory, the more robust are the research outcomes (Rowley, 2002). The multiple sources approach was used in this research. 


\section{Data collection}

Semi-structured interviews have the ability to facilitate an in-depth inquiry into the issues (Kulatunga et al., 2011). Therefore, semi-structured interviews were used as the main method of data collection. The interview process used in the research followed the approach used by Kulatunga et al. (2011), where the interviews were kept open ended to the maximum possible extent to allow the interviewees to feel free to express their views. The interviews centred on the theme "why those things happened". However, at the same time, care also was taken not to restrict new themes or concepts from emerging. At least two persons were interviewed for each case. This process enabled to understand issues from at least two distinctive perspectives as well as to triangulate findings to arrive at firm findings. All the interview transcripts were audio tape-recorded and manually transcribed.

\section{Case study selection}

Case study selection was done to cover a wide spread of areas such as the following:

- Large and small (cost wise) projects;

- Different delivery types such as traditional, Design and Build, PPP; and

- Different types of clients such as public and private.

All case studies were from Australia. The following were the case studies considered:

1. Construction of a large hospital building. Cost around Aus $\$ 2$ Billion. Significant innovations included: being one of the first billion dollar health projects in Australia where Building Information Modelling (BIM) was applied so extensively, including the collaborative use of dRofus (Room database software linked to the 3D model) to its full extent; innovative renewable and energy efficient infrastructure, which used an innovative twin duct system; buildings constructed from non-toxic materials and is considered to be a 'healthy' hospital, offering fresh air and natural light.

2. Major rehabilitation of a bridge. Cost around Aus $\$ 30$ Million. Significant innovations included: new methods to clean the joints and bearings and a new jacking system used for the first time in the organization. A new material was used for friction plates for the first time in bridges in Australia.

3. Construction of a bikeway. Cost around Aus $\$ 750,000$. Significant innovations included: innovative construction methods to protect the roots of pine hoop trees, making a bridge with fibre composite material, using ground penetrating radar for finding out the root locations of hoop pine trees, all for the first time in the organization.

4. Major intersection upgrade. Cost around Aus $\$ 300$ Million. Significant innovations included: an effective way of staging of work, increase of bypass height considered not possible by designers due to terrain posed restrictions.

The level of innovativeness was determined after considering the following factors:

- The novelty of innovations developed;

- The number of innovations developed; and

- The impact from innovations.

These three factors were in line with the 14 variables used in the questionnaire part, which were grouped into project outcomes, project recognition and project usage. The impact from innovations was measured using project outcomes (example, increased productivity and competitive advantage) and project usage (example, use of improved technologies, methods and practices). The novelty of innovations developed was measured using project recognition (example, project receiving internal recognition). As the innovativeness of 
projects was assessed (and not the innovativeness of individual innovations) it was necessary to consider the number of innovations developed as well.

For example, the case study on the construction of a large hospital building had the following innovations:

- One of the first billion dollar health projects in Australia where Building Information System (BIM) was applied extensively.

- Included the collaborative use of dRofus (Room database software linked to the 3D model) to its full extent.

- Introduced an innovative renewable and energy efficient infrastructure, which used an innovative twin duct system.

- Buildings were constructed from non-toxic materials and was considered to be a 'healthy' hospital, offering fresh air and natural light.

Some of these were novel innovations and all had positive impacts on productivity and environment and contributed to considerable savings. Therefore, this building construction was considered as highly innovative.

\section{Case study results}

Table $V$ shows the performance of each construct of the conceptual model (i.e., idea harnessing, relationship enhancement, incentivization and project team fitness) for each case study.

\begin{tabular}{|c|c|c|c|c|}
\hline $\begin{array}{l}\text { Project } \\
\text { details }\end{array}$ & Idea harnessing & $\begin{array}{l}\text { Relationship } \\
\text { enhancement }\end{array}$ & Incentivization & $\begin{array}{l}\text { Project team } \\
\text { fitness }\end{array}$ \\
\hline $\begin{array}{l}1 \text { Construction } \\
\text { of a large } \\
\text { hospital } \\
\text { building. } \\
\text { Project cost } \\
\text { very high (Aus } \\
\$ 2 \text { Billion). } \\
\text { This is a PPP } \\
\text { project. } \\
\text { Highly } \\
\text { innovative. }\end{array}$ & $\begin{array}{l}\text { Very strong in idea } \\
\text { harnessing. A large } \\
\text { number of idea } \\
\text { harnessing } \\
\text { techniques were } \\
\text { used and strategies } \\
\text { adopted. }\end{array}$ & $\begin{array}{l}\text { No formal relationship } \\
\text { enhancement } \\
\text { agreements. However, it } \\
\text { is evident that all parties } \\
\text { had strong relationships } \\
\text { with each other. Most of } \\
\text { the client's project team } \\
\text { members have worked } \\
\text { previously with the } \\
\text { contractor's project } \\
\text { management team, } \\
\text { establishing good } \\
\text { relationships. As the client } \\
\text { team and the contractor's } \\
\text { team represented one } \\
\text { organization helped closer } \\
\text { bonding of team } \\
\text { members. }\end{array}$ & $\begin{array}{l}\text { Past innovation } \\
\text { history has been } \\
\text { considered when } \\
\text { appointing the } \\
\text { designer. No } \\
\text { personal or } \\
\text { financial incentives } \\
\text { provided. } \\
\text { However, it is } \\
\text { evident that there } \\
\text { was a strong } \\
\text { desire to do best } \\
\text { work by each team } \\
\text { member. } \\
\text { Challenges due to } \\
\text { constraints also } \\
\text { provided } \\
\text { motivation for } \\
\text { innovations. }\end{array}$ & $\begin{array}{l}\text { Technically } \\
\text { competent, highly } \\
\text { experienced } \\
\text { project team } \\
\text { members drawn } \\
\text { from different } \\
\text { areas of the } \\
\text { organization to } \\
\text { represent the } \\
\text { contractor's team. } \\
\text { Very effective, } \\
\text { strong, technically } \\
\text { competent project } \\
\text { manager who } \\
\text { encouraged } \\
\text { innovation. } \\
\text { Innovative parent } \\
\text { organization. }\end{array}$ \\
\hline $\begin{array}{l}2 \text { Major } \\
\text { rehabilitation } \\
\text { of a bridge. } \\
\text { Project cost } \\
\text { low to } \\
\text { moderate - } \\
\text { around Aus } \\
\$ 30 \text { Million. }\end{array}$ & $\begin{array}{l}\text { Brainstorming and } \\
\text { learnings from past } \\
\text { projects were } \\
\text { heavily used. } \\
\text { Operational level } \\
\text { staff contributed } \\
\text { mostly with novel } \\
\text { ideas. }\end{array}$ & $\begin{array}{l}\text { Strong relationship } \\
\text { between the client's and } \\
\text { contractors' teams was } \\
\text { evident. Both teams } \\
\text { coming from the same } \\
\text { organization would have } \\
\text { contributed to the strong } \\
\text { relationship. }\end{array}$ & $\begin{array}{l}\text { Challenges due to } \\
\text { constraints and the } \\
\text { need to show } \\
\text { excellence by the } \\
\text { contractor provided } \\
\text { motivations for } \\
\text { innovations. }\end{array}$ & $\begin{array}{l}\text { Technically } \\
\text { competent, highly } \\
\text { experienced } \\
\text { project team of } \\
\text { the contractor. } \\
\text { Very effective, } \\
\text { strong, technically } \\
\text { competent project } \\
\text { manager who }\end{array}$ \\
\hline
\end{tabular}




\begin{tabular}{|c|c|c|c|c|}
\hline $\begin{array}{l}\text { Cost plus } \\
\text { project. } \\
\text { Significantly } \\
\text { innovative. }\end{array}$ & & & & $\begin{array}{l}\text { encouraged } \\
\text { innovation. } \\
\text { Moderately } \\
\text { innovative parent } \\
\text { organization. }\end{array}$ \\
\hline $\begin{array}{l}3 \text { Construction } \\
\text { of a bikeway. } \\
\text { Project cost } \\
\text { low around } \\
\text { Aus } \$ 750,000 \text {. } \\
\text { Design and } \\
\text { build project. } \\
\text { Moderately } \\
\text { innovative. }\end{array}$ & $\begin{array}{l}\text { Project team } \\
\text { investigated } \\
\text { solutions to the } \\
\text { constraints imposed } \\
\text { on the project. } \\
\text { Small project team. }\end{array}$ & $\begin{array}{l}\text { Fairly strong relationship } \\
\text { between the client's and } \\
\text { contractors' teams was } \\
\text { evident. } \\
\text { However, the project team } \\
\text { consisted of members } \\
\text { from two competing state } \\
\text { organizations, therefore, } \\
\text { were not close enough in } \\
\text { relationships due to inter- } \\
\text { organizational rivalry. }\end{array}$ & $\begin{array}{l}\text { Challenges due to } \\
\text { constraints } \\
\text { provided } \\
\text { motivations for } \\
\text { innovation. No } \\
\text { other incentives } \\
\text { were provided. }\end{array}$ & $\begin{array}{l}\text { Less experienced } \\
\text { project manager } \\
\text { with average } \\
\text { skills and } \\
\text { moderately } \\
\text { innovative client } \\
\text { organization. }\end{array}$ \\
\hline $\begin{array}{l}\text { 4 Major } \\
\text { intersection } \\
\text { upgrade. } \\
\text { Project cost } \\
\text { moderate to } \\
\text { high - around } \\
\text { Aus } \$ 300 \\
\text { Million. } \\
\text { Significantly } \\
\text { innovative. } \\
\text { Double ECI } \\
\text { contract. }\end{array}$ & $\begin{array}{l}\text { Most of idea } \\
\text { harnessing } \\
\text { techniques and } \\
\text { strategies adopted. } \\
\text { The nature of } \\
\text { Double ECl contract } \\
\text { contributed to } \\
\text { generating } \\
\text { beneficial ideas, } \\
\text { especially because } \\
\text { the client bought } \\
\text { the design of the } \\
\text { unsuccessful } \\
\text { bidder. }\end{array}$ & $\begin{array}{l}\text { This was a collaborative } \\
\text { contract with strong } \\
\text { relationship between } \\
\text { parties initially. However, } \\
\text { when the contract } \\
\text { company was bought over } \\
\text { by another company, the } \\
\text { relationship became poor. } \\
\text { All parties working in the } \\
\text { same building helped } \\
\text { building fairly good } \\
\text { relationships. }\end{array}$ & $\begin{array}{l}\text { The motivation to } \\
\text { win the contract } \\
\text { provided incentive } \\
\text { to the bidding } \\
\text { parties to look for } \\
\text { innovative } \\
\text { solutions. }\end{array}$ & $\begin{array}{l}\text { Very effective, } \\
\text { strong, technically } \\
\text { competent project } \\
\text { manager who } \\
\text { encouraged } \\
\text { innovation. } \\
\text { Moderately } \\
\text { innovative client } \\
\text { organization. }\end{array}$ \\
\hline
\end{tabular}

\section{Table V. The performance of conceptual model constructs}

From the Table $\mathrm{V}$ a trend can be seen that more idea harnessing efforts are contributing to better innovative outcomes. It can be seen that good relations existed in all cases between parties. As all four cases were innovative in varying degrees, it can be argued that good relationships contributed to innovative performance. It is also to be noted that the least innovative case (Case 3 ) had a low performance in terms of relationship (the project team consisted of members from two competing state organizations, therefore, were not close enough in relationships due to inter-organizational rivalry). It is also apparent that Australian construction clients offer little or no monetary or personal incentives for innovation. The innovations happening in these projects could be attributed mostly to the desire of the project team to overcome challenges and to the self-satisfaction of team members of doing best of their abilities. However, the two most innovative projects had some incentives. In the most innovative project, the past innovation history has been considered when appointing the designer, conveying the message that innovation is important and could be considered when selecting designers for future projects. The next most innovative project used a competitive bidding strategy, which provided incentives to the bidding parties to look for innovative solutions for winning the contract. It can be seen that the project team fitness was very high in the most innovative case (Case 1) and not so high in the least innovative case of Case 3 (lowest performance when compared to others). This indicated that higher project team fitness resulted in higher innovation performance, especially with the increased effectiveness of the project manager. 
Therefore, it is apparent that with increased performance of constructs (i.e., idea harnessing, relationship enhancement, incentivization and project team fitness), the innovation performance of the project gets better.

These results validate the conceptual model in promoting innovation in construction projects by clients, where it was shown that the constructs of idea harnessing, relationship enhancement, incentivization and project team fitness contribute to innovation performance. However, this validation technique could not be used to assess the inter-relationship between constructs.

\section{Empirical model related findings}

The same case studies were used to assess the innovative performance in relation to the empirical model constructs, namely; project team attributes, support to the project team, nature of relationship, project team member attributes, internal recognition, client organization, designers and contractors selection and incentivization. The findings clearly showed that each construct promoted innovation performance.

Due to space limitation, the details on the validation of the empirical model are not given here. However, they can be found in Fernando (2019).

\section{Discussion}

This research was focussed on testing and validating a previously developed conceptual model to describe innovation enablers in construction projects. The analysis of survey data collected from projects in Australia using factor analysis and correlation analysis led to develop an empirical model. The constructs belonging to the empirical model are given in Table 1. The left column gives the name of the construct and the right column gives the list of variables containing under each construct. Each variable has a number containing one of the following letters before the description: $A, B, C$ and $D$. These letters denote the groups of constructs they belonged to in the conceptual model, i.e. idea harnessing (Group A), relationship enhancing (Group B), incentivization (Group C) and project team fitness (Group D).

By examining the Table 1 it can be seen that 'Project team attributes' has items from Group $A$ (idea harnessing) and $D$ (project team fitness). Other constructs also have variables from the conceptual model. These relationships are shown in Figure 3. 'Relationships between the variables belonging to both models'.

It can be seen that all the constructs of the conceptual model, i.e. idea harnessing, relationship enhancement, incentivization and project team fitness, which were identified during the literature review, were included in the constructs belonging to the empirical model. This shows that although looked different, the empirical model was a manifestation of the conceptual model. It provides evidence that although the conceptual model was developed with world-wide research findings, it is a valid representation of the current Australian construction industry and can be used to represent the actual phenomena prevalent in the practical world. 


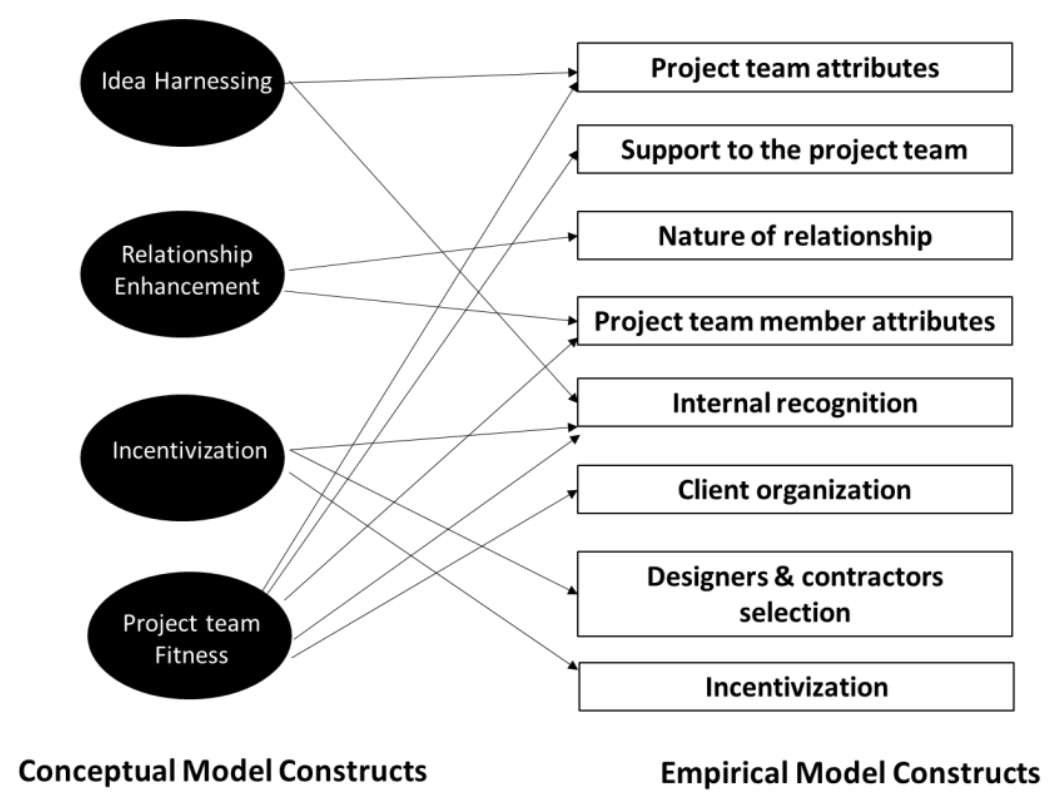

Figure 3. Relationships between the variables belonging to both models

Due to its limitations, the validation method, i.e. the case study approach, could not assess the inter-relationship among constructs for both models. Validating these relationships will help to improve the academic understanding of the innovation process happening at the project level in construction projects. However, it will not be of much use for practical purposes, where the requirement is to find a model to describe innovation enabler categories that promote innovation for the use of clients.

As we have not been able to validate the inter-relationship among constructs, we present the model in Figure 1 as our recommended model.

\section{Conclusions}

This research was conducted to fill a significant knowledge gap that existed in the area of construction innovation at the project level. Complexity of factors that contributed to innovation at the project level in construction has been a barrier to progress with comprehensive research in this area. As Ozorhon (2012) pointed out, the project level innovation has largely been ignored due to the difficulties in monitoring the different activities conducted by different parties in each stage of a construction project. The fact that no two projects are identical to each other has exacerbated this difficulty. This study provided theoretical and empirical evidence that help to unravel the complex relationships of client-led factors that contribute to promote innovation in construction projects. For the first time, the research was able to find a simple way of categorizing the complex activities happening in construction projects due to the actions of clients that help promoting innovation and derive a simple model that can be used by clients interested in promoting innovation.

In this research, the client-led innovation enablers were categorized under four major areas, i.e. idea harnessing, relationship enhancement, incentivization and project team fitness. As the model had only these four constructs, which are self-explanatory, the model can be considered as simple, uncomplicated, and easy to understand by clients. In addition, the innovation enablers identified can be implemented by clients themselves without seeking external assistance from the policy makers such as federal, state and local governments or industry players such as professional organizations. 
The research findings have the potential to uplift the current knowledge in this area in different ways.

- One of the main findings of the study is that idea harnessing influences innovative outcomes. Although this finding is not new in the broader context of innovation, the authors are of the opinion that this is the first time that it's applicability in the construction project level has been proven with empirical evidence. Now it is possible to invest effort to identify idea harnessing techniques and processes at the project level to promote innovation.

- Although not proven in the construction project level context, industry practitioners have been using contractual processes such as partnering and contract types such as alliances to enhance relationship between parties. With this proven validity of the strong association between enhanced relationship within parties to a construction project resulting in higher innovative outcomes, more focus can now be given to find better practices that enhance relationships in the construction world.

- The influence of incentivization on innovative outcomes is another crucial finding with significant ramifications. As revealed in the research, many practitioners in the construction industry in Australia have failed to utilize this valuable approach to promote innovation in construction projects. However, the importance of incentivization to promote innovative performance in projects is highlighted in innovation literature by many scholars including Dulaimi et al. (2002), Eriksson et al. (2007), Ibrahim et al. (2017), Love et al. (2010), Tawiah and Russel (2008) and Winch (1998). The findings in relation to this category of innovation enablers has provided the spotlight on the need to focus more on utilizing incentivization for enhanced innovative outcomes.

- The other finding that project team fitness influences innovation in construction projects is also accepted in the construction industry although not proven previously in the project level context. Many factors contribute to build a capable project team driving innovation in construction projects. The appointment of a technically competent, highly skilled project manager and the parent organization taking actions to be more innovative are two outstanding factors that came out prominently in the research, which future researchers may concentrate their efforts to expand the knowledge further.

If the research findings are used by clients to promote innovation in construction projects, they can achieve significant benefits.

In addition to presenting a model to identify innovation enablers for construction projects, this research also introduced a definition for project level innovation which will help to have clarity and a common understanding of this subject area.

With the use of innovation as a tool in construction projects as introduced here, we strongly believe that the success rate of construction projects will start improving substantially.

\section{Acknowledgement}

Retired Professor Dayananda Palahela of the University of St. Thomas, USA is kindly acknowledged for the advice and guidance on matters related to the statistical analysis.

\section{References}

Asuero, A., Sayago, A. and Gonzalez, A. (2006), "The correlation coefficient: An overview", Critical reviews in analytical chemistry, vol. 36 , no. 1, pp. 41-59. 
Bhattacherjee, A. (2012), Social Science Research: principles, methods, and practices, vol. Book 3, USF Tampa Bay Open Access Textbooks Collection.

Bolboaca, S.D. and Jäntschi, L. (2006), "Pearson versus Spearman, Kendall's tau correlation analysis on structure-activity relationships of biologic active compounds", Leonardo Journal of Sciences, vol. 5, no. 9, pp. 179-200.

Brockmann, C., Brezinski, H. and Erbe, A. (2016), "Innovation in Construction

Megaprojects", Journal of Construction Engineering and Management, vol. 142, no. 11, pp. 04016059:1-9.

Chen, H.L. (2014), "Innovation stimulants, innovation capacity, and the performance of capital projects", Journal of Business Economics and Management, vol. 15, no. 2, pp. 21231.

Chok, N.S. (2010), "Pearson's versus Spearman's and Kendall's correlation coefficients for continuous data", Masters thesis, University of Pittsburgh, Pittsburgh, USA.

Costello, A.B. and Osborne, J.W. (2009), "Best practices in exploratory factor analysis: Four recommendations for getting the most from your analysis", Pan-Pacific Management

Review, vol. 12, no. 2, pp. 131-46.

Crowe, S., Cresswell, K., Robertson, A., Huby, G., Avery, A. and Sheikh, A. (2011), "The case study approach", BMC Medical Research Methodology, vol. 11, no. 100, pp. 1-9.

Field, A. (2013), Discovering Statistics using IBM SPSS Statistics, vol. Fourth Edition, SAGE Publications Inc.

Duffield, C. and Maghsoudi, S. (2013), "Innovation for Infrastructure Projects", University of Melbourne, available at:

https://www.researchgate.net/publication/267568961_Innovation_for_Infrastructure_Projects $>$ (accessed 12 May 2020).

Dulaimi, M.F., Ling, F.Y.Y., Ofori, G. and De Silva, N. (2002), "Enhancing integration and innovation in construction", Building research \& information, vol. 30, no. 4, pp. 237-47.

Eriksson, P.E., Dickinson, M. and Khalfan, M.M.A. (2007), "The influence of partnering and procurement on subcontractor involvement and innovation", Facilities, vol. 25, no. 5/6, pp.

203-14.

Fernando, S. (2019), "Analysis of client-led innovation enablers in construction projects", $\mathrm{PhD}$ thesis, University of Southern Queensland, Toowoomba, Australia.

Fernando, S., Panuwatwanich, K. and Thorpe, D. (2019), "Analyzing client-led innovation enablers in Australian construction projects", International Journal of Managing Projects in Business, vol. 13, no. 2, pp. 388-408.

Gennarelli, R. and Goodman, M.S. (2013), "Measuring Internal Consistency of Community Engagement using the APLHA option of PROC CORR", in NESUG SAS Conference, Burlington, Vermont, USA.

Hair, J.F., Black, W.C., Babin, B.J., Anderson, R.E. and Tatham, R.L. (2006), Multivariate Data Analysis, vol. Sixth Edition, Pearson Education Inc.

Ibrahim, C.K.I.C., Costello, S.B., Wilkinson, S. and Walker, D. (2017), "Innovation in alliancing for improved delivery of road infrastructure projects", International Journal of Managing Projects in Business, vol. 10, no. 4, pp. 700-20.

Keegan, A. and Turner, J.R. (2002), "The management of innovation in project-based firms", Long range planning, vol. 35, no. 4, pp. 367-88.

Kulatunga, K., Kulatunga, U., Amaratunga, D. and Haigh, R. (2011), "Client's championing characteristics that promote construction innovation", Construction Innovation: Information, Process, Management, vol. 11, no. 4, pp. 380-98.

Kumar, N., Kumar, O., Badagabettu, S.N., Lewis, M.G., Adiga, M. and Padur, A.A. (2018), "Determination of Spearman Correlation Coefficient ( $r$ ) to Evaluate the Linear Association of Dermal Collagen and Elastic Fibers in the Perspectives of Skin Injury", Dermatology Research and Practice, pp. 1-6.

Love, P.E.D., Davis, P.R., Chevis, R. and Edwards, D.J. (2010), "Risk/reward compensation model for civil engineering infrastructure alliance projects", Journal of Construction

Engineering and Management, vol. 137, no. 2, pp. 127-36. 
Mukaka, M.M. (2012), "Statistics Corner: A guide to appropriate use of Correlation coefficient in medical research", Malawi Medical Journal, vol. 24, no. 3, pp. 69-71.

Ozorhon, B. (2012), "Analysis of construction innovation process at project level", Journal of Management in Engineering, vol. 29, no. 4, pp. 455-63.

Pollack, J. and Adler, D. (2015), "Emergent trends and passing fads in project management research: A scientometric analysis of changes in the field", International Journal of Project Management, vol. 33, no. 1, pp. 236-48.

Rowley, J 2002, "Using case studies in research", Management Research News, vol. 25, no. 1, pp. 16-27.

Schell, C. (1992), "The Value of the Case Study as a Research Strategy", available at: http://dbs.uni-leipzig.de/file/aumueller05wiksar.pdf (accessed 16 October 2018).

Sedgwick, P. (2012), "Pearson"s correlation coefficient", Bmj, vol. 345, no. 7, pp. 1-2. Tawiah, P.A. and Russel, A.D. (2008), "Assessing infrastructure project innovation potential as a function of procurement mode", Journal of Management in Engineering, vol. 24, [no issue no],pp. 173-186.

Uchitpe, M., Uddin, S. and Lynn, C. (2016), "Predicting the Future of Project Management Research", Procedia - Social and Behavioral Sciences, vol. 226, pp. 27-34.

Williams, B., Onsman, A. and Brown, T. (2010), "Exploratory factor analysis: A five-step guide for novices", Australasian Journal of Paramedicine, vol. 8, no. 3, pp. 1-13. Winch, G. (1998), "Zephyrs of creative destruction: understanding the management of innovation in construction", Building research \& information, vol. 26, no. 5, pp. 26879. Yong, A.G. and Pearce, S. (2013), "A beginner's guide to factor analysis: Focusing on exploratory factor analysis", Tutorials in Quantitative Methods for Psychology, vol. 9, no. 2, pp. 79-94. 